\title{
Establishment and Characteristics of Five Analbuminemic Inbred Strains of Rats
}

\author{
Seigo SHUMIYA, Susumu ANDO*, Kazuo KON*, and Sumi NAGASE** \\ Department of Laboratory Animals, *Department of Biochemistry, Tokyo \\ Metropolitan Institute of Gerontology 35-2 Sakae-cho, Itabashi-ku, \\ Tokyo 173, and **Department of Chemistry, Sasaki Institute, \\ 2-2 Kanda-Surugadai, Chiyoda-ku, Tokyo 101, Japan
}

(Received 3 April 1987/Accepted 17 July 1987)

\begin{abstract}
Five analbuminemic inbred strains of rats $(\mathrm{AD} / 1, \mathrm{AD} / 2, \mathrm{AD} / 3, \mathrm{AD} / 4, \mathrm{AD} / 5)$ were established from Nagase analbuminemic rats (NAR). They showed no genetic differences in coat color, biochemical marker gene loci and skin grafting test. Their serum levels of total cholesterol, phospholipids, triglycerides, and $\beta$-lipoproteins were compared with normal inbred strains (L) derived from Sprague-Dawley rats. Their plasma apoproteins were also examined. All inbred strains of analbuminemic rats showed hyperlipidemia progressing with age although there were slight variations in their lipid and apoprotein levels. These analbuminemic inbred strains of rats may be multigenic models of lipid metabolism abnormality.
\end{abstract}

In 1977, Nagase et al. [12,13] established an analbuminemic mutant strain of rats (NAR; Nagase Analbuminemic Rat) from outbred Sprague-Dawley rats. The analbuminemia is inherited by a single recessive autosomal gene (alb) [16] which was linked to the hooded locus belonging to the sixth linkage group [17]. Biochemically, the mutant is characterized by exrtaordinarily low levels of serum albumin and hyperlipidemia, but these characteristics are assumed to be modified by the genetic background and rearing environment [15].

Therefore, we have tried to establish analbuminemic strains of rats with unified genetic backgrounds and established the three analbuminemic congenic strains (ACI-alb, F344-alb, and SHR-alb) [18]. The present paper describes the establishment of five inbred strains of analbuminemic rats from NAR and several characteristics of these strains.

\section{Materials and Methods}

Original individuals for inbreeding were selected randomly from NAR stock. Attempts to establish analbuminemic inbred strains were made twice. The first started in 1977 [13] and the second in 1980.

Throughout the experiments, the rats were put in cages $(265 \times 425 \times 200 \mathrm{~mm})$ with wood shavings on the floor and kept in an Iso-Rack (Sanki Scientific Co. Ltd., Tokyo) into which a gentle flow of fresh air filtered by double microfilters was supplied horizontally from the back wall. They were maintained at the Sasaki Institute in the conventional animal room with air-conditioning (23 $\pm 2^{\circ} \mathrm{C}$ and $55 \pm 5 \%$ relative humidity) and artificial lighting with 12 hours of light from $7 \mathrm{AM}$ to $7 \mathrm{PM}$, and provided with a commercial diet (CE-2: CLEA Japan Inc., To- 
kyo) and tap water ad libitum.

Pregnant females were removed to individual cages for delivery and rearing after three weeks of pairing with males.

Serum total cholesterol concentrations were measured in each generation at seven weeks of age with blood samples collected from the tip of the tail. The established analbuminemic inbred strains of rats were monitored using more than five rats with regard to some coat color and biochemical marker gene loci as described previously [18]. The skin grafting test was carried out by the method of Festing and Grist [5]. Mature rats were anesthetized with sodium-pentobarbital, and a $7 \mathrm{~mm}$ square section of the tail skin of each rat was cut off and transplanted with the direction of hair growth reversed. Results of the skin graft were judged two weeks after the operation. Some biochemical analyses were carried out for characterization of the established strains. Serum total cholesterol (TC), phospholipids (PL), and triglycerides (TG) were analyzed by conventional enzyme methods with a photoelectric colorimeter (Klett Manufacturing Co. Inc., New York). $\beta$-lipoproteins were examined by precipitation with heparin and calcium ions [10] at 7,10 , and 15 weeks of age in five rats of either sex. Serum lipoperoxide (LPO) was assayed by the fluorometric method [20] at 10 and 15 weeks of age in three rats of both sexes. In three females at 5 weeks of age the apolipoprotein composition of plasma lipoproteins ( $d$ $\leq 1.21$ ) isolated by ultracentrifugal flotation at $40,000 \mathrm{rpm}$ for 24 hours were analyzed by sodium dodecyl sulfate polyacrylamide gel electrophoresis (Fig. 1) [8].

\section{Results and Discussion}

In the first experiment on inbreeding of NAR [13], two sibmating lines died out at the F7 and F6 generations. The breeding data of the two lines at the $\mathrm{F} 6$ generation are shown in Table 1 . We could obtain three pairs in the $A$ line and one pair in the $B$ line. They delivered five and three litters, respectively. However, none of the three pairs set up in the former line at the F7 generation delivered pups, and no females were obtained in the latter line in three de-

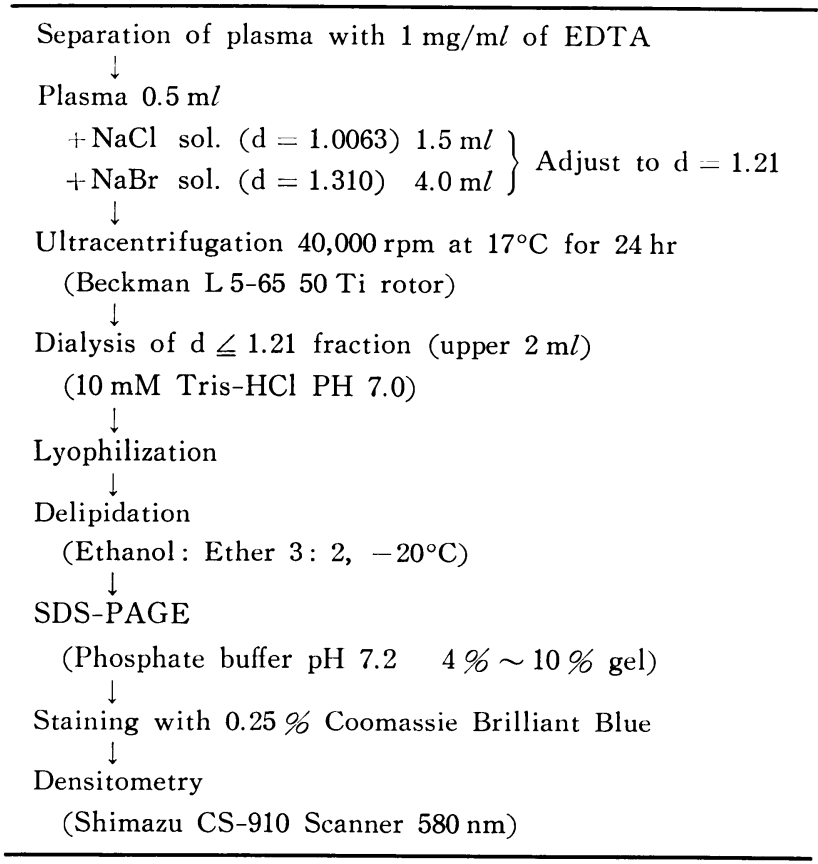

Fig. 1. Analytical methods for plasma apoproteins. 
Table 1. Breeding data of F6 generation in inbreeding lines of analbuminemic rats.

\begin{tabular}{ccccccc}
\hline \multirow{2}{*}{$\begin{array}{c}\text { Delivery } \\
\text { No. }\end{array}$} & $\begin{array}{c}\text { Litter } \\
\text { size }\end{array}$ & $\begin{array}{c}\text { A line } \\
\text { Weaned }\end{array}$ & pups & \multicolumn{2}{c}{ B line } & Litter \\
male & female & Weaned & pups \\
\cline { 5 - 7 } & 10 & 2 & 1 & 8 & 1 & 0 \\
2 & 4 & 0 & 0 & 7 & 3 & 0 \\
3 & 6 & 4 & 1 & 8 & 0 & 0 \\
4 & 2 & 0 & 0 & & & \\
5 & 6 & 3 & 3 & & & \\
\hline
\end{tabular}

Table 2. Serum lipid concentrations of analbuminemic rats in the first inbreeding lines.

\begin{tabular}{cccccc}
\hline \multirow{2}{*}{ Generation } & \multicolumn{2}{c}{ Total cholesterol $(\mathrm{mg} / \mathrm{d} l)$} & & \multicolumn{2}{c}{ Triglycerides $(\mathrm{mg} / \mathrm{d} l)$} \\
3 & \multicolumn{1}{c}{ male } & female & & male & female \\
F 4 & $128 \pm 12(5)^{*}$ & $128 \pm 16(5)$ & & $134 \pm 38(5)$ & $195 \pm 59(5)$ \\
F 5 & $147 \pm 10(11)$ & $151 \pm 13(20)$ & & $197 \pm 30(11)$ & $212 \pm 74(20)$ \\
& $179 \pm 15(8)$ & $217 \pm 20(13)$ & & $273 \pm 61(8)$ & $251 \pm 56(13)$
\end{tabular}

$*$ mean $\pm \mathrm{SD}(\mathrm{n})$

\begin{tabular}{|c|c|c|c|c|c|c|c|c|}
\hline & A line & B & $B$ line & c line & $D$ line & & E line & $R$ line \\
\hline $\mathbf{P}$ & 吅 & & 무 & 이 & o & & श口 & 이 \\
\hline FI & 它颔㚪 & & 如 & 呫 & 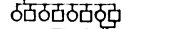 & & 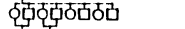 & 就 \\
\hline $\mathrm{F} 2$ & 哞和 & & 沾 & 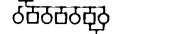 & 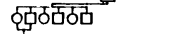 & & 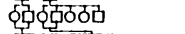 & 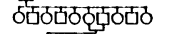 \\
\hline$F_{3}$ & 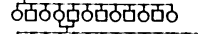 & & 政 & 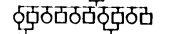 & 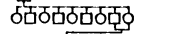 & & 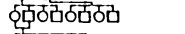 & 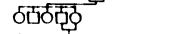 \\
\hline $\mathrm{F}_{4}$ & 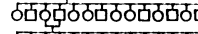 & 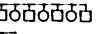 & die & 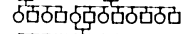 & 吼颔顽䀡 & & 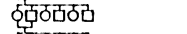 & 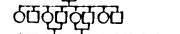 \\
\hline F5 & 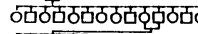 & & out & 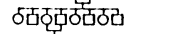 & 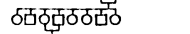 & & 颔颔吔 & 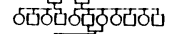 \\
\hline F6 & 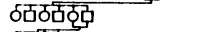 & & & 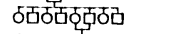 & 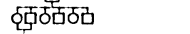 & & 岾呴 & 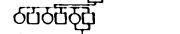 \\
\hline F7 & 颔䏦 & & & 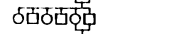 & 岾吼 & & 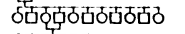 & 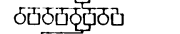 \\
\hline F8 & 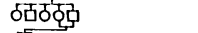 & & & 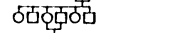 & 颔㗁咍 & & 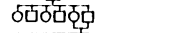 & 响额 \\
\hline F9 & 㚲 & & & 颀岾 & 顿颔码 & & 喕耐烦 & 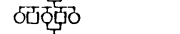 \\
\hline F10 & 敌词 & & & 吅占战 & 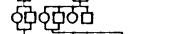 & & ót話敌 & 蚂需吼 \\
\hline F11 & 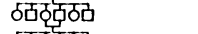 & & & 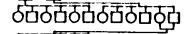 & 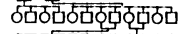 & & 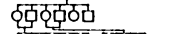 & 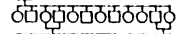 \\
\hline $\mathrm{F} 12$ & 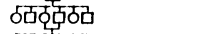 & & & 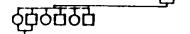 & 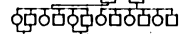 & & 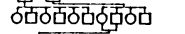 & 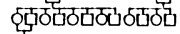 \\
\hline F 13 & 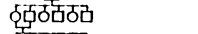 & & & 占颔顿 & 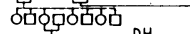 & 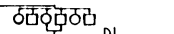 & 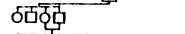 & 论颔 \\
\hline F14 & 品顿码 & & & 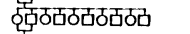 & 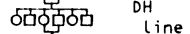 & 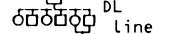 & 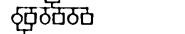 & 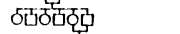 \\
\hline F15 & 战ర & $0:$ female & & 岾吗 & 颗呫 & 颔顿顿 & 乩䖨吸 & 顿顿埙 \\
\hline F16 & 它吸 & 口: mate & & 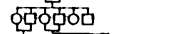 & 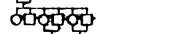 & 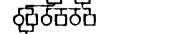 & 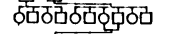 & 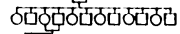 \\
\hline F17 & die & & & 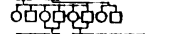 & 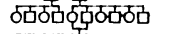 & 㚲ठठరठठ & 颔战話 & 鸹 \\
\hline F18 & & & & 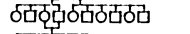 & 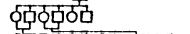 & 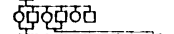 & 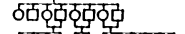 & 就ठठ \\
\hline F19 & & & & 吅岾吼 & 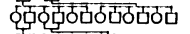 & 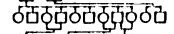 & 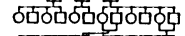 & 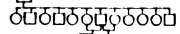 \\
\hline $\mathrm{F} 20$ & & & & 呫乩颔 & 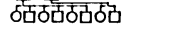 & 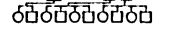 & 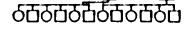 & 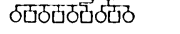 \\
\hline & & & & $A D / 1$ & $A D / 2$ & $A D / 3$ & $A D / 4$ & $A D / 5$ \\
\hline
\end{tabular}

Fig. 2. Pedigree maps of the analbuminemic rats.

liveries at the $\mathrm{F} 6$ generation. The infertile parents had atrophied testes and ovaries and hydro-uterus. One cause of this extinction appeared to be an infection such as mycoplasmosis. Another reason seemed to be unusual physiological conditions due to hyperlipidemia accelerated by the inbreeding ('Table 2). We again tried inbreeding six lines selectea randomly from the NAR colony to study the cause of the extinction and to establish strains with high coefficients of inbreeding and relationship.

At the beginning, we intended to continue brother and sister matings as much as 
possible but changed to the three-line rotation system when the animal stocks were about to become extinguished [19]. These inbred lines were continuously used to supply nuclear breeders of NAR stock which were propagated by random breeding to counterbalance genetic drift. We finally established five analbuminemic lines with over twenty generations of brother-sister matings. A pedigree map of each line is shown in Fig. 2. The A line died out at the F16 generation, apparently caused by a high incidence of infertile females from the early generations. The $\mathrm{B}$ line was weeded out at the F3 generation because of frequent cannibalism and infertility. After the F12 generation, the $\mathrm{D}$ line was divided into two lines with high (DH) and low (DL) levels of total cholesterol concentration at seven weeks of age. The established five inbred strains $(\mathrm{C}, \mathrm{DH}, \mathrm{DL}, \mathrm{E}, \mathrm{R})$ were designated as $\mathrm{AD} / 1, \mathrm{AD} / 2, \mathrm{AD} / 3, \mathrm{AD} / 4$, and $\mathrm{AD} / 5$, respectively. At present, outbred NASs are produced by random matings among nuclear breeders taken from these five inbred strains.

The five analbuminemic lines and the normal inbred strain (L) derived from Sprague-Dawley rats had difterent cholesterol levels (Fig. 3). The five analbuminemic lines showed no increase in TC values with successive inbreeding generations. $\mathrm{AD} / 1$ had the highest mean $\mathrm{TC}$ values of $171 \mathrm{mg} / \mathrm{d} l$ in males and $189 \mathrm{mg} / \mathrm{d} l$ in females. $\mathrm{AD} / 3 \mathrm{had}$ the lowest values of 131 and $163 \mathrm{mg} / \mathrm{d} l$ in males and females, respectively. In contrast, the $\mathrm{L}$ line had 60 and $66 \mathrm{mg} / \mathrm{d} l$ in males and females, respectively. Thus, clear differences

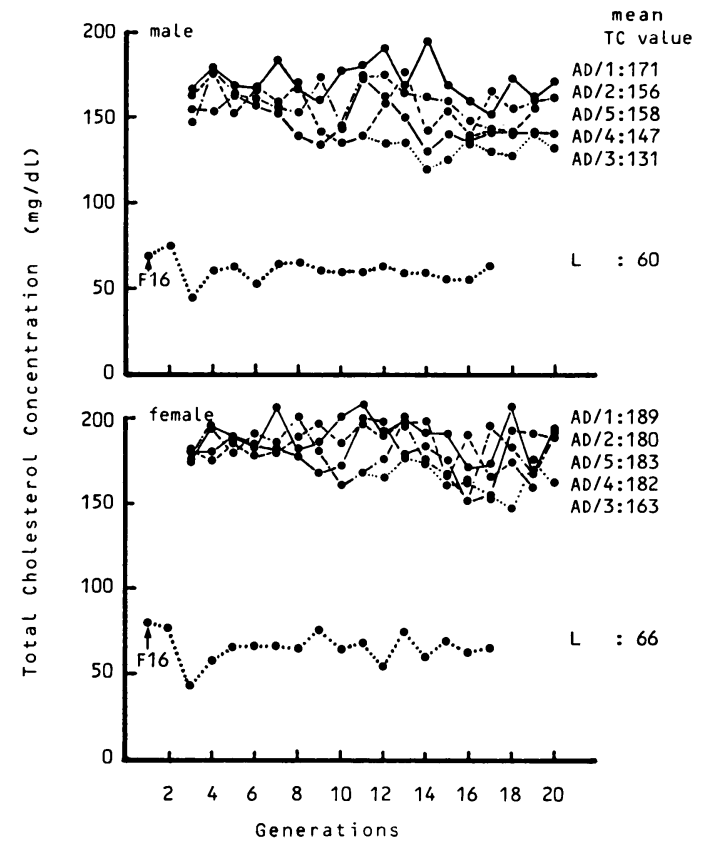

Fig. 3. Total cholesterol concentrations in rat sera at 7 weeks of age in each generation.

appeared between the five analbuminemic lines and the $\mathrm{L}$ line.

Results of genetic monitoring of the five established analbuminemic inbred strains are shown in Table 3. The ACI, DONRYU and TM strains were used as renference strains for each marker gene. Among the five analbuminemic inbred strains, there were no differences in marker genes at coat color $(a$, $b, c, h)$ and biochemical marker gene loci Amy-1, Cs-1, Es-1, Es-2, Es-3, Es-4, Hbb, alb, Gc). Results of inter-and intra-strain

Tabel 3. Coat color and biochemical marker genes of analbuminemic inbred strains of rats.

\begin{tabular}{cccccccccccccc}
\hline Strain & $\mathrm{a}$ & $\mathrm{b}$ & $\mathrm{c}$ & $\mathrm{h}$ & $A m y-1$ & $C s-1$ & $E s-1$ & $E s-2$ & $E s-3$ & $E s-4$ & $H b b$ & $\mathrm{alb}$ & $G c$ \\
\hline $\mathrm{AD} / 1$ & $\mathrm{a}$ & $\mathrm{B}$ & $\mathrm{c}$ & $\mathrm{h}$ & $\mathrm{a}$ & $\mathrm{b}$ & $\mathrm{a}$ & $\mathrm{a}$ & $\mathrm{b}$ & $\mathrm{b}$ & $\mathrm{b}$ & - & $\mathrm{a}$ \\
$\mathrm{AD} / 2$ & $\mathrm{a}$ & $\mathrm{B}$ & $\mathrm{c}$ & $\mathrm{h}$ & $\mathrm{a}$ & $\mathrm{b}$ & $\mathrm{a}$ & $\mathrm{a}$ & $\mathrm{b}$ & $\mathrm{b}$ & $\mathrm{b}$ & - & $\mathrm{a}$ \\
$\mathrm{AD} / 3$ & $\mathrm{a}$ & $\mathrm{B}$ & $\mathrm{c}$ & $\mathrm{h}$ & $\mathrm{a}$ & $\mathrm{b}$ & $\mathrm{a}$ & $\mathrm{a}$ & $\mathrm{b}$ & $\mathrm{b}$ & $\mathrm{b}$ & - & $\mathrm{a}$ \\
$\mathrm{AD} / 4$ & $\mathrm{a}$ & $\mathrm{B}$ & $\mathrm{c}$ & $\mathrm{h}$ & $\mathrm{a}$ & $\mathrm{b}$ & $\mathrm{a}$ & $\mathrm{a}$ & $\mathrm{b}$ & $\mathrm{b}$ & $\mathrm{b}$ & - & $\mathrm{a}$ \\
$\mathrm{AD} / 5$ & $\mathrm{a}$ & $\mathrm{B}$ & $\mathrm{c}$ & $\mathrm{h}$ & $\mathrm{a}$ & $\mathrm{b}$ & $\mathrm{a}$ & $\mathrm{a}$ & $\mathrm{b}$ & $\mathrm{b}$ & $\mathrm{b}$ & - & $\mathrm{a}$ \\
$\mathrm{ACI}$ & $\mathrm{A}$ & $\mathrm{B}$ & $\mathrm{C}$ & $\mathrm{h}$ & $\mathrm{b}$ & $\mathrm{a}$ & $\mathrm{b}$ & $\mathrm{a}$ & $\mathrm{a}$ & $\mathrm{b}$ & $\mathrm{b}$ & + & $\mathrm{a}$ \\
DONRYU & $\mathrm{a}$ & $\mathrm{B}$ & $\mathrm{c}$ & $\mathrm{h}$ & $\mathrm{a}$ & $\mathrm{b}$ & $\mathrm{a}$ & $\mathrm{c}$ & $\mathrm{b}$ & $\mathrm{a}$ & $\mathrm{a}$ & + & $\mathrm{a}$ \\
$\mathrm{TM}$ & $\mathrm{a}$ & $\mathrm{B}$ & $\mathrm{C}$ & $\mathrm{h}$ & $\mathrm{b}$ & $\mathrm{a}$ & $\mathrm{b}$ & $\mathrm{a}$ & $\mathrm{c}$ & $\mathrm{a}$ & $\mathrm{b}$ & + & $\mathrm{b}$ \\
\hline
\end{tabular}




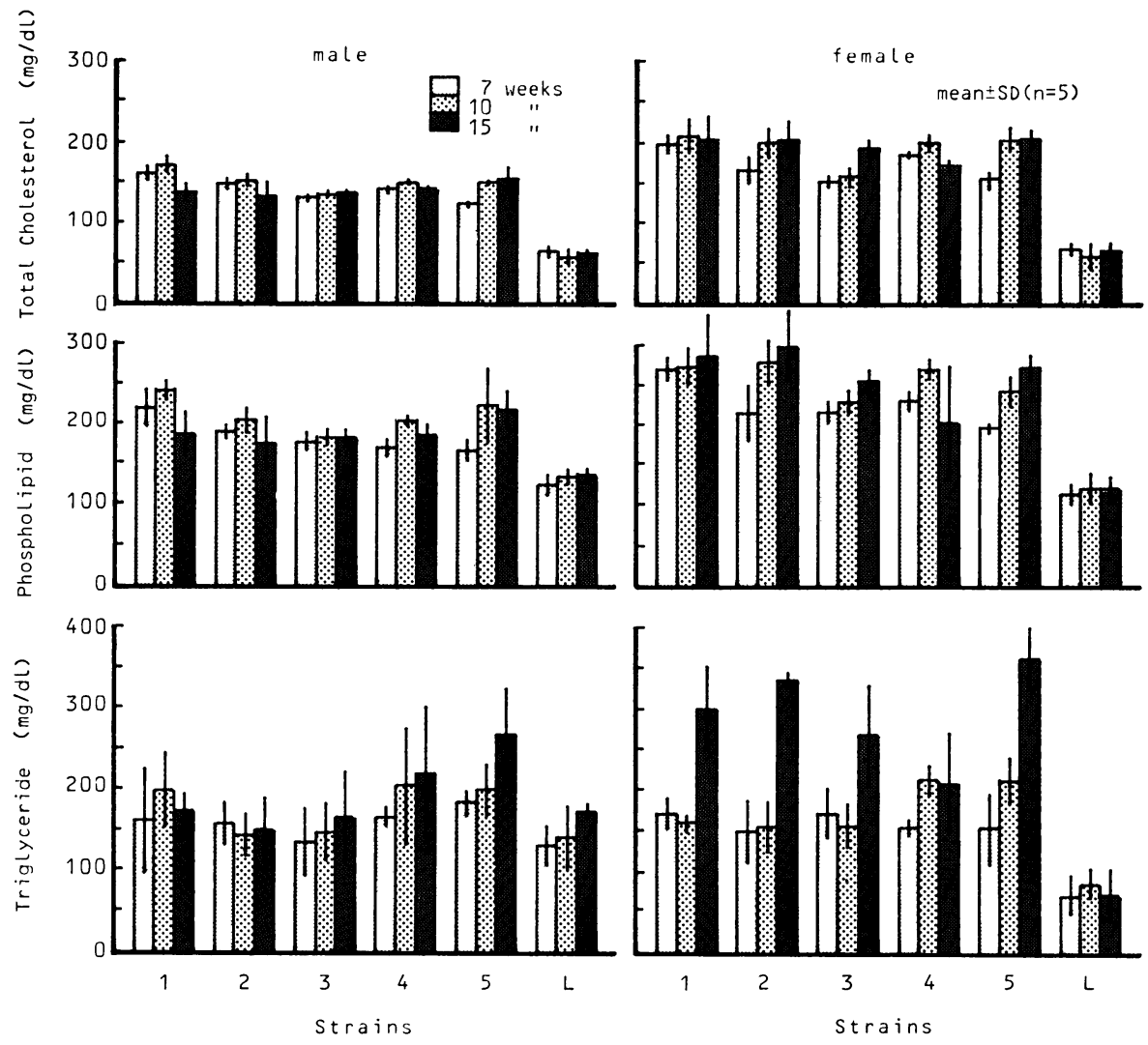

1-5: analbuminemia; $\mathrm{L}$ : normal low lipidemia

Fig. 4. Serum lipid concentratins in each strain.

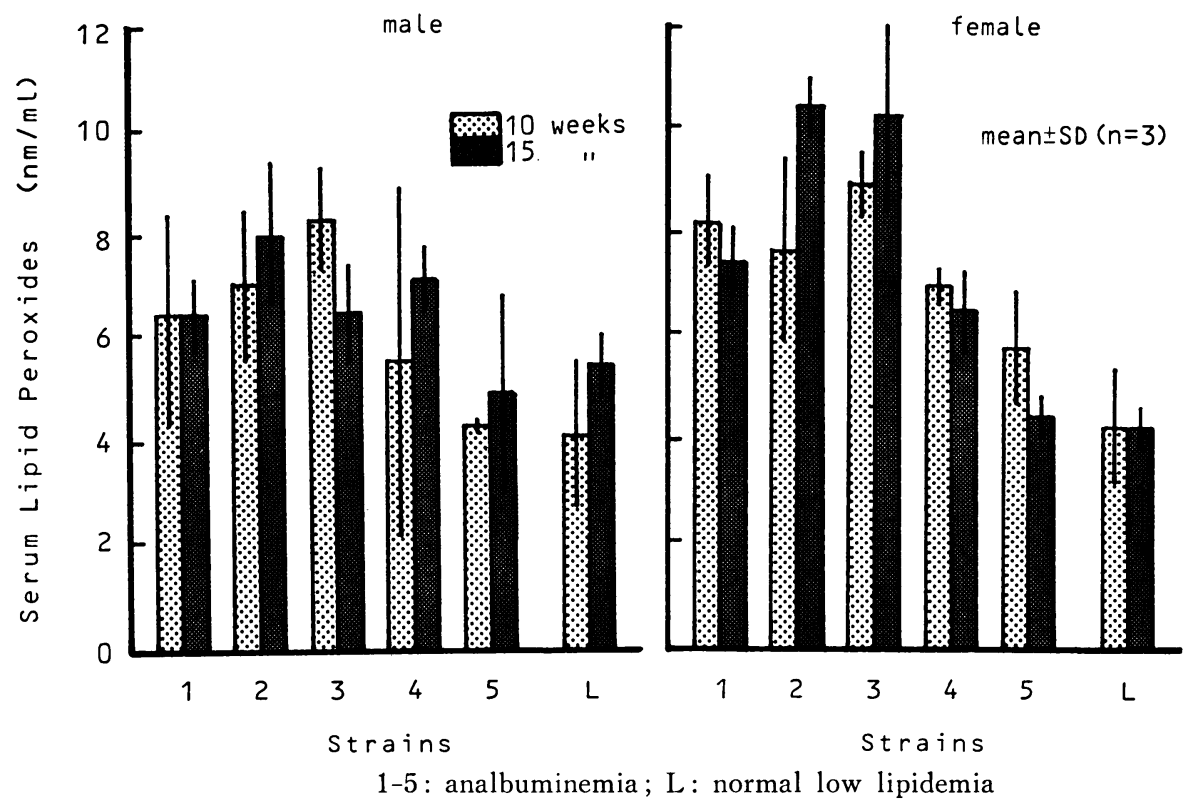

Fig. 5. Serum lipoperoxide value in each strain. 
Table 4. Results of inter-and intra-strain skin grafting.

\begin{tabular}{ccccccc}
\hline & $\mathrm{AD} / 1$ & $\mathrm{AD} / 2$ & $\mathrm{AD} / 3$ & $\mathrm{AD} / 4$ & $\mathrm{AD} / 5$ & $\mathrm{~L}$ \\
\cline { 2 - 6 } $\mathrm{AD} / 1$ & + & + & + & + & + & - \\
$\mathrm{AD} / 2$ & & + & + & + & + & - \\
$\mathrm{AD} / 3$ & & & + & + & + & - \\
$\mathrm{AD} / 4$ & & & & + & + & - \\
$\mathrm{AD} / 5$ & & & & & + & - \\
$\mathrm{L}$ & & & & & & + \\
\hline
\end{tabular}

+ : reciprocal acceptance, - : reciprocal rejection

L : normal inbred strain originating from outbred Sprague-Dawley rats.

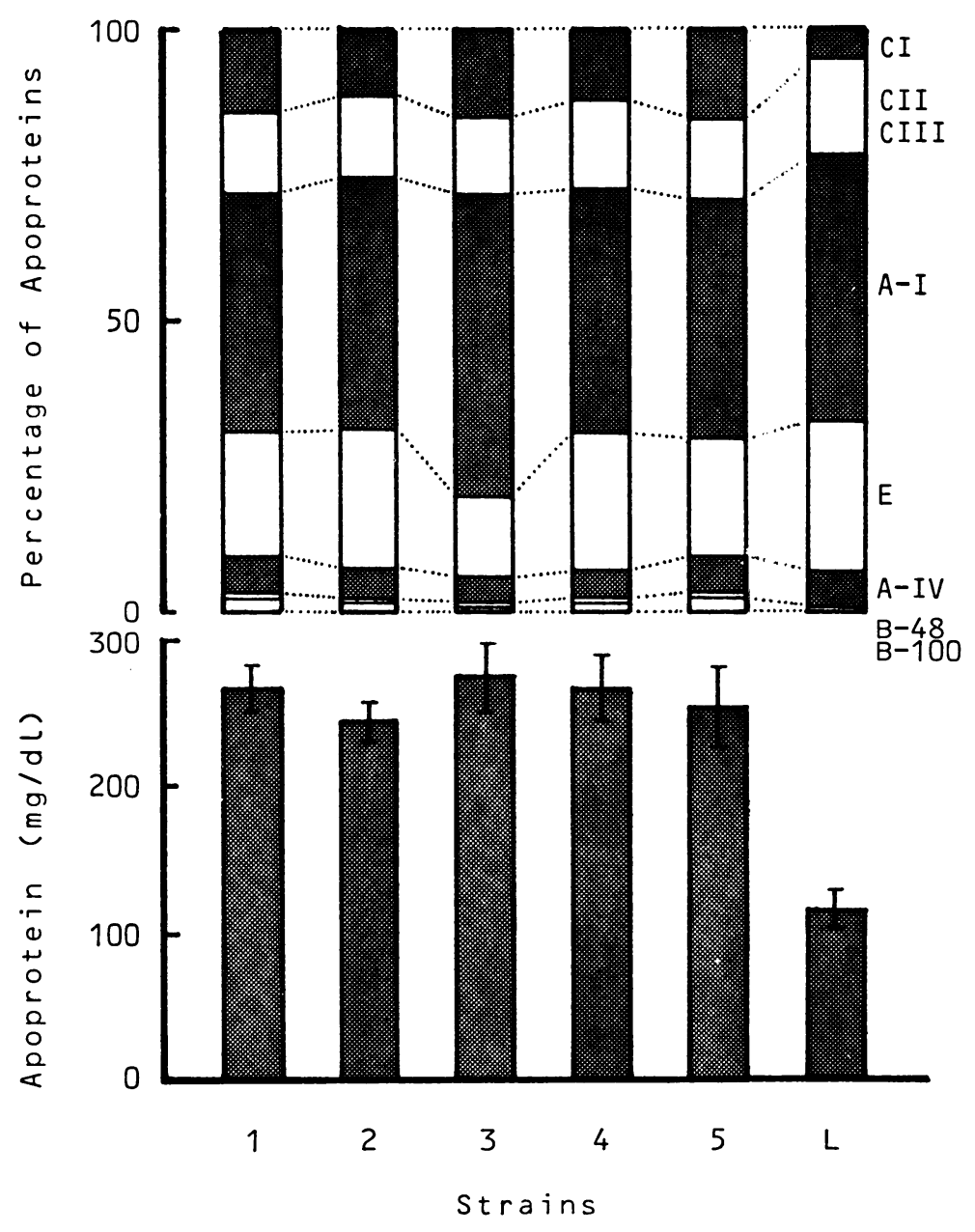

1-5: analbuminemia; L: normal low lipidemia

Fig. 6. Plasma apoprotein concentration and relative amount of its constituents in female rats at 15 weeks of age. 
skingrafting are shown in Table 4. Garfts of the five analbuminemic strains were accepted reciprocally, but were rejected by the $\mathrm{L}$ strain. Original NARs are derived from the outbred stock of Sprague-Dawley rats. They were delivered to us at the $\mathrm{F} 4$ generation after divergence [13]. Several heterozygosities in the $E s-1, E s-3, E s-4$, and $H b b$ loci appear in the outbred stock of Sprague-Dawley rats (Katoh, H. et al.: Parsonal communication). This and the above results suggest that the NAR stock was a population with a high level of homozygosity from an early stage.

Serum lipid concentrations (TC, PL, TG) at 7, 10 and 15 weeks of age are shown in Fig. 4. In the analbuminemic strains, serum lipid concentrations tended to increase with age although in cholesterol was small. Strain differences appeared in the lipid concentrations; $\mathrm{AD} / 1$ and $\mathrm{AD} / 5$ always showed higher levels. In contrast, the other three strains sometimes showed slightly lower levels compared with those two strains, Higher serum $\mathrm{LPO}$ appeared in the $\mathrm{AD} / 2$ and $\mathrm{AD} / 3$ strains, which showed relatively lower cholesterol levels (Fig. 5). The cause of this phenomenon is uncertain and further investigations are required to elucidate the underlying mechanism. Concentration of plasma apoproteins and the relative amount of its constituents in females at 15 weeks of age are shown in Fig. 6. A clear difference in the total apoprotein value appeared between the analbuminemic rats and the $\mathrm{L}$ strain. The $\mathrm{AD} / 2$ strain showed the lowest value among the analbuminemic strains. In the $\mathrm{AD} / 3$ strain, the apoA-I concentration was high and apoE was low. Among the minor components, apoB constituted $3.58 \%$ in strain $\mathrm{AD} / 1,2.54 \%$ in $\mathrm{AD} / 2,1.35 \%$ in $\mathrm{AD} / 3,2.13 \%$ in $\mathrm{AD} / 4,3.18$ $\%$ in $\mathrm{AD} / 5$ and $0.56 \%$ in the $\mathrm{L}$ strain.

Recently, genetic studies of human apolipoproteins have progressed rapidly and the structures of most apolipoprotein genes have been determined [4]. The complete amino acid sequence of human apoB has also been confirmed by tow groups of resarchers $[9,21]$. The structure of rat apolipoproteins A-I, A-II, $\mathrm{A}-\mathrm{IV}, \mathrm{C}-\mathrm{III}$, and $\mathrm{E}$ genes has been analyzed $[1-3,6,7,11,14]$, and the evolutionary relationships with human apolipoprotein are apparent. Thus it appears that there are characteristics in each analbuminemic strain for the regulation of apoproteins. The five established analbuminemic inbred strains of rats may serve as multigenic models of lipid metabolism abnormality.

\section{References}

[1] Boguski, M. S. et al. (1986). Evolution of the apolipoproteins. J. Biol. Chem. 261, 6398-6407.

[2] Boguski, M.S. et. al. (1985). Comparative analysis of repeated sequences in rat apolipoproteins A-I, A-IV, and E. Proc. Natl. Acad. Sci. USA, 82, 992-996.

[3] Boguski, M. S. et al. (1984). Rat apolipoprtein A-IV contains 13 tandem repetition of a 22 -amino acid segment with amphipathic helical potential. Pro. Natl. Acad. Sci. USA, 81, 5021-5025.

[4] Breslow, J.L. (1986). Genetics of the human apolipoproteins. Biochemistry and Biology of Plasma Lipoproteins (ed. Scanu, A.M. and Spector, A.A.) pp. 85-143, Dekker, NY.

[5] Festing, M.F.W., and Grist, S. (1970). A simple technique for skin grafting rats. Lab. Anim. 4, 255-258.

[6] Fung, W.P. ct al.(1986). Structure and expression of the rat apoliporotein E gene. J. Biol. Chem. 261, 13777-13783.

[7] Haddad, I. A. et al. (1986). Linkage, evoltion, and expression of the rat apolipoprotein A-I, CIII, and A-IV genes. J. Biol. Chem. 261, 1326813277.

[8] Havel, R. J. et al. (1955). The distribution and chemical composition of ultracentrifugally separated lipoproteins in human serum. J. Clin. Invest. 34, 1345-1353

[9] Knott, T. J. et al. (1986). Complete protein sequence and identification of structural domains of human apolipoprotein B. Nature, 323, 734-738.

[10] Koide, A. et al. (1975). Analysis of serum lipoproteins by precipitation with heparin and calcium ions. Rinsho Byori, 21 (suppl.), 89-91 (in Japanese).

[11] Mclean, J. W. et al. (1983). Rat apolipoprotein E mRNA. J. Biol. Chem., 258, 8993-9000.

[12] Nagase, S. et al. (1979). Albumin-deficient rat mutant. Science. 205, 590-591.

[13] Nagase, S. et al. (1980). Albumin-deficient rat mutant: An animal model for analbuminemia. Exp. Anim., 29, 33-38.

[14] Nagashima, M. ct al. (1986). Amino acid sequence of rat apolipoprotein A-II deduced from the nucleotide sequence of cloned CDNA. J. Lipid Res., 27, 706-712.

[15] Russell, W. M. S., and Burch, R. L. (1959). The Principles of Humane Experimental Technique. $238 \mathrm{p}$ Methnen, London.

[16] Shumiya, S., and Nagase, S. (1981). Establishment of an albumin-deficient and jaundiced strain of rats. Exp. Anim., 30,291-297. 
[17] Shumiya, S. and Nagase, S. (1982). Linkage of the analbuminemia locus (alb) and the hooded locus in the rat, Rattus Norvegicus. Exp. Anim., 31, 199-202.

[18] Shumiya, S. and Nagase, S. (1986). Establishnent and chracteristics of three analbuminemic congenic strains of rats. Exp. Anim., 35, 409-416.

[19] Wakasugi, N. and Kondo, K. (1973). Breeding methods for maintenance of mutant genes and establishment of strains in the Japanese quail. Exp. Anim., 22, (suppl.), 151-159.

[20] Yagi, K. (1976). A simple fluometric assay for lipoperoxide in blood. Biochem. Med., 15, 212216.

[21] Yang, C. Y. et al. (1986). Sequence, structure, recepter-binding domains and internal repeats of human apolipopretein B-100. Nature, 323, 738742 .

\title{
5 系統の無アルブミン近交系ラットの育成とその特性
}

\author{
朱宮正剛・安藤 進*·近一夫*·長瀬すみ** \\ 財東京都老人総合研究所実験動物研究室 \\ * (䀿東京都老人総合研究所生化学部臨床第二研究室 \\ ** 財佐々木研究所生化学部
}

無アルブミン血症ラット（NAR）をもとにして，5系 統の無アルブミン近交系ラット $(\mathrm{AD} / 1, \mathrm{AD} / 2, \mathrm{AD} / 3$, $\mathrm{AD} / 4, \mathrm{AD} / 5)$ を育成した。乙れらの 5 系統間には毛色, 生化的標識遗伝子座および皮庙移植試験による遺伝的差 異は認められなかった。血清中の総コレステロール，燐 脂質, 中性脂質および $\beta$ ーリポタンパク, 血漿アポタン パクについて, SD ラット由来の正常近交系ラット
と比較した。その結果, すべての無アルブミン近交系ラ ットは著しい高脂血症を示し, 加龄とともに増加する傾 向が認められた。また， 5 系統の近交系間には脂質とア ポタンパクレベルにわずかな変異が認められた。今回育 成した 5 系統の無アルブミン近交系ラットは脂質代識異 常に関する複合モデルとなる可能性がある。 